\title{
Two New Haplotypes of Bartonella sp. Isolated from Lipoptena fortisetosa (Diptera: Hippoboscidae) in SE Poland
}

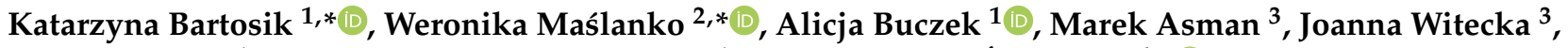 \\ Ewelina Szwaj ${ }^{1}$, Paweł Szczepan Błaszkiewicz ${ }^{1}$ and Magdalena Świsłocka ${ }^{4, *}$ (1) \\ 1 Chair and Department of Biology and Parasitology, Faculty of Health Sciences, Medical University of Lublin, \\ Radziwiłłowska 11 St., 20-080 Lublin, Poland; alicja.buczek@umlub.pl (A.B.); szwajewelina@gmail.com (E.S.); \\ blaszkiewicz_pawel@interia.pl (P.S.B.) \\ 2 Department of Animal Ethology and Wildlife Management, Faculty of Animal Sciences and Bioeconomy, \\ University of Life Sciences in Lublin, Akademicka 13 St., 20-950 Lublin, Poland \\ 3 Department of Parasitology, Faculty of Pharmaceutical Sciences in Sosnowiec, Medical University of Silesia, \\ Jedności 8 St., 41-200 Sosnowiec, Poland; masman@sum.edu.pl (M.A.); jwitecka@sum.edu.pl (J.W.) \\ 4 Department of Zoology and Genetics, Faculty of Biology, University of Bialystok, Ciołkowskiego 1J St., \\ 15-245 Białystok, Poland \\ * Correspondence: katarzyna.bartosik@umlub.pl (K.B.); weronika.maslanko@up.lublin.pl (W.M.); \\ magdaswi@uwb.edu.pl (M.Ś.)
}

check for updates

Citation: Bartosik, K.; Maślanko, W.; Buczek, A.; Asman, M.; Witecka, J.; Szwaj, E.; Błaszkiewicz, P.S.;

Świsłocka, M. Two New Haplotypes of Bartonella sp. Isolated from Lipoptena fortisetosa (Diptera: Hippoboscidae) in SE Poland. Insects 2021, 12, 485. https://doi.org/ $10.3390 /$ insects 12060485

Academic Editor: Koichi Goka

Received: 2 May 2021

Accepted: 21 May 2021

Published: 24 May 2021

Publisher's Note: MDPI stays neutral with regard to jurisdictional claims in published maps and institutional affiliations.

Copyright: (c) 2021 by the authors. Licensee MDPI, Basel, Switzerland. This article is an open access article distributed under the terms and conditions of the Creative Commons Attribution (CC BY) license (https:/ / creativecommons.org/licenses/by/ $4.0 /)$.
Simple Summary: Lipoptena fortisetosa is a hematophagous ectoparasite of game animals feeding accidentally on companion animals and humans. Since the presence of numerous pathogenic microorganisms has been described in this species, monitoring its geographic distribution is of great epidemiological importance. To the best of our knowledge, we present two new haplotypes of Bartonella sp. isolated from L. fortisetosa in south-eastern Poland and confirm the presence of this invasive species in Lublin Voivodeship since 2013.

Abstract: Insects of the genus Lipoptena are parasitic arthropods with a broad host range. Due to the type of parasitism (hematophagy), their potential role as vectors of pathogens, i.e., Bartonella sp., Anaplasma phagocytophilum, Rickettsia spp., and Borrelia burgdorferi is considered. As the range of their occurrence has been changing dynamically in recent years and infestations of humans have increasingly been reported, these organisms are now the subject of numerous studies. Our research aimed to present the molecular characteristics of Bartonella sp. detected in Lipoptena fortisetosa parasitizing wild cervids in south-eastern Poland. Adults of Lipoptena spp. were collected from carcasses of roe deer and red deer between spring and autumn in 2013. The PCR method was used to detect Bartonella sp. in the insects. We report two new haplotypes of the rpoB gene of Bartonella sp. isolated from L. fortisetosa feeding on wild cervids in south-eastern Poland and the presence of this invasive ectoparasitic species in the studied area since 2013. Phylogenetic analyses of newly obtained Bartonella sp. haplotypes confirmed their unique position on the constructed tree and network topology. The rpoB gene sequences found belonging to lineage B support the view that this phylogenetic lineage represents a novel Bartonella species.

Keywords: Lipoptena sp.; deer keds; invasive species; Cervus elaphus; ectoparasites; wild cervids

\section{Introduction}

Five of the 32 species of Lipoptena deer keds (Diptera: Hippoboscidae) widespread in the world fauna occur in Europe [1,2]. Two species, i.e., Lipoptena cervi (Linnaeus, 1758) and Lipoptena fortisetosa Maa, 1965, inhabit the central and northern parts of the continent. In recent years, progressive expansion of L. cervi [3-7] and L. fortisetosa [8-15] has been observed. As shown by literature data, the spread of L. fortisetosa species in Europe was most likely caused by its natural dispersal outside Asia, overlapping the ranges of Siberian 
and European roe deer during periodic climate changes, or by introduction with alien mammal species, e.g., sika deer (Cervus nippon Temminck, 1838) [16,17].

In Poland, L. fortisetosa was first found in Lower Silesia at the end of the 1980s [18]. This deer ked species was found again in 2007-2014 on red deer (Cervus elaphus Linnaeus, 1758) and roe deer (Capreolus capreolus Linnaeus, 1758) in the north $[19,20]$, in environments in north-eastern and southern Poland, including the Polish part of the Tatra Mountains [21,22], and recently in northern and western Poland [23].

Depending on the geographical region as well as climate and ecological conditions, the level of prevalence and severity of invasion of specific ectoparasites varies significantly, e.g., in the case of L. cervi, it mainly depends on the host species [4,24] and exhibits seasonal differences: the highest prevalence is most often noted in autumn and winter [25]. L. cervi parasitize domestic and wild animals, primarily representatives of Cervidae-red deer, roe deer, and moose (Alces alces Linnaeus, 1758) [15,26], own observations. The L. fortisetosa host species have not been clearly defined, but they are probably the same animals as the hosts of L. cervi $[13,16]$. Human infestations by Lipoptena adults in their habitats are increasingly being reported. Their bites cause dermatitis in humans [3,27-29]. In animals, the parasitism of these flies induces clinical symptoms related to anemia and skin mechanical damage [30,31].

In Lipoptena spp., microorganisms causing human and animal diseases have been detected. These include, e.g., Anaplasma ovis [32], Anaplasma phagocytophilum [23,33], Bartonella sp. [23,34-40], Borrelia burgdorferi [33], Rickettsia spp. [23,32], Trypanosoma spp. [41,42], Coxiella-like bacteria, Theileria luwenshuni, and Theileria ovis endosymbionts [23,43]. This fact contributed to the increased interest in the potential involvement of these arthropods in maintenance of foci of zoonotic diseases. In north-eastern Poland, researchers detected in L. cervi sequences of Bartonella sp. with $99 \%$ similarity with B. schoenbuchensis [44]. The presence of Bartonella sp. was also noted in L. fortisetosa sampled from cervids and from the environment in the northern and western parts of the country [23].

Our study presents the molecular characteristics of Bartonella sp. detected in L. fortisetosa parasitizing wild cervids in south-eastern Poland.

\section{Materials and Methods}

\subsection{Sampling}

Specimens of Lipoptena were collected in spring and autumn 2013 from carcasses of C. capreolus and C. elaphus harvested by hunters in accordance with the Act of 13 October 1995 (Hunting Law, Journal of Laws 2018, item 2033 as amended) near Polesie National Park (51 $23^{\prime} 39^{\prime \prime}$ N $23^{\circ} 11^{\prime} 4^{\prime \prime}$ E) (Figure 1). These animals were culled in accordance with the Annual Hunting Plans in selected hunting circles operating in the studied macroregion, during hunting periods indicated in the Regulation of the Minister of the Environment of 16 March 2005 on the determination of hunting periods for game animals (Journal of Laws 2005, No. 48, item 459). Ectoparasites collected from the animals were placed in sterile plastic test tubes with $70 \%$ ethanol. 


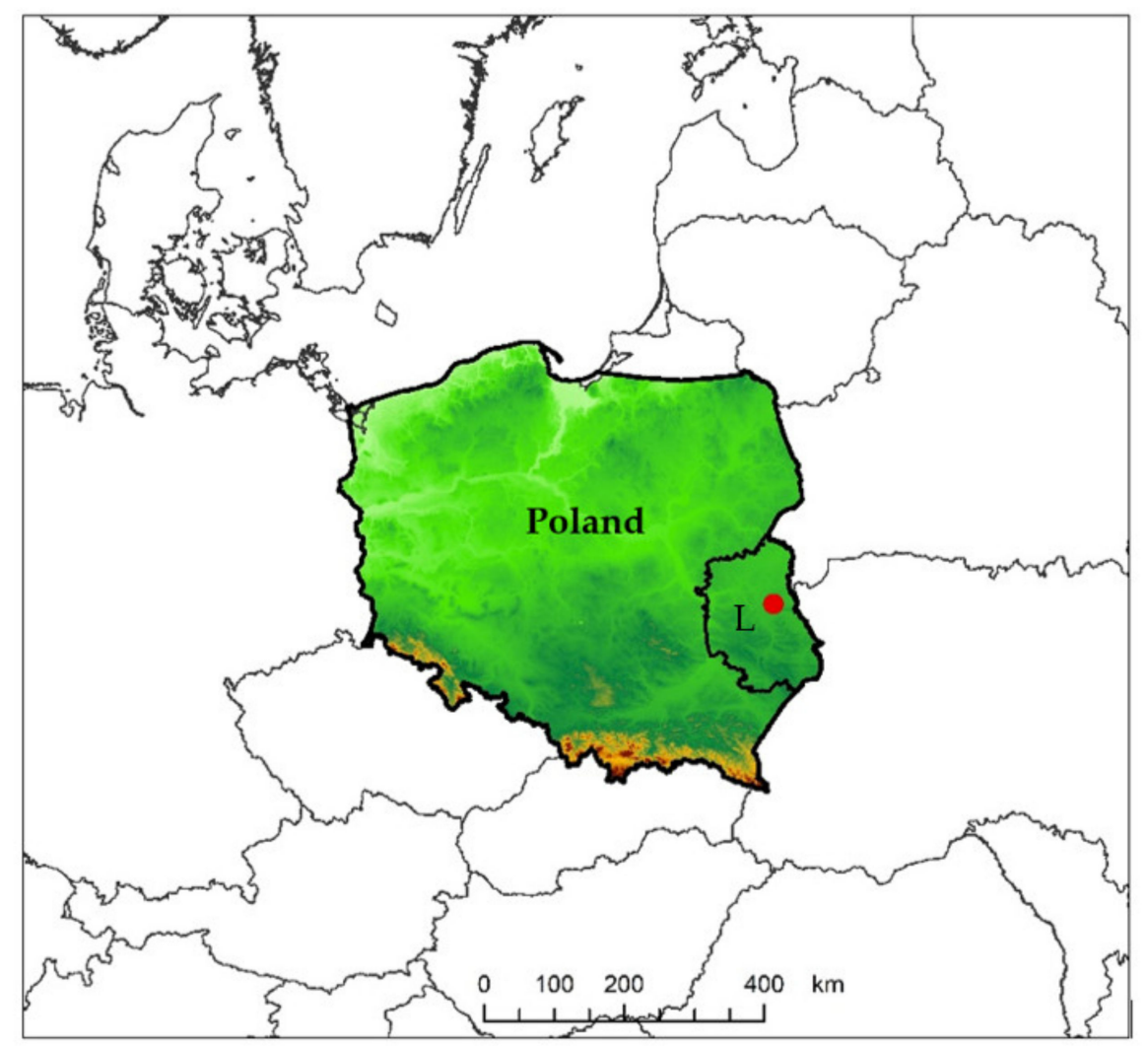

Figure 1. Research area in south-eastern Poland, L-Lublin Voivodeship.

\subsection{Species Identification}

Identification of the species and sex of the adult insects was carried out in the laboratory using an OLYMPUS SZX16 (Olympus, Tokyo, Japan) stereoscopic microscope and the key for identification of arthropod species compiled by Borowiec [45].

\subsection{Molecular Analysis}

\subsubsection{DNA Extraction and Polymerase Chain Reaction}

The molecular analysis included 24 specimens of Lipoptena spp., each blood-fed adult from a different animal host. The DNA from $15 \mathrm{~L}$. cervi (6 females and 9 males) and $9 \mathrm{~L}$. fortisetosa ( 7 females and 2 males) randomly selected for the pilot study was isolated with the ammonia method [46]. Next, its concentration was measured spectrophotometrically using a nanospectrophotometer Pearl (Implen, Germany) at a 260/280 wavelength. Then, the samples were frozen at $-20^{\circ} \mathrm{C}$ and stored until further analysis. The PCR method and a pair of primers $(1400 \mathrm{~F}$ and $2300 \mathrm{R})$ specific to the rpoB gene were used to detect Bartonella sp. in the insects [47]. The amplification product was separated electrophoretically in $2 \%$ ethidium bromide-stained agarose gel. Then, the gel was visualized in ultraviolet light in an Omega 10 device (Ultra Lum, Claremont, CA, USA). Next, the samples were analyzed with the use of Total Lab software (TotalLab, Newcastle-Upon-Tyne, UK). The presence of an 825 base pair PCR product was treated as positive. Next, this product was isolated from the agarose gel with the use of an Agarose Out kit (EURx, Gdansk, Poland) according to the manufacture's protocol and sequenced (Genomed, Warsaw, Poland).

\subsubsection{Sequencing and Phylogenetic Analysis}

The resulting sequences of the $r p o B$ gene for RNA polymerase beta subunit were aligned and revised manually in BioEdit v7.0.4 [48]. The obtained sequences were submitted to GenBank. To test the phylogenetic relationships among our newly obtained rpoB gene haplotypes and sequences downloaded from GenBank, we constructed a phylogenetic tree using a maximum-likelihood (ML) algorithm in Mega v5.05 [49] with 1000 bootstrap 
replicates. The GTR $+\mathrm{I}+\mathrm{G}$ model of substitution was selected as the best-fitting model by the AIC test (Akaike Information Criterion) with jModelTest [50] for the ML tree. We also calculated and visualized the relationships among founders in our study and downloaded rpoB gene haplotypes from GenBank by constructing a haplotype network using the medianjoining method available in Network version 10.2.0.0 (http:/ / www.fluxus-engineering.com (accessed on 10 February 2021).

\section{Results}

Two species, i.e., L. cervi and L. fortisetosa, were identified among the Lipoptena adults collected from C. elaphus and C. capreolus. The preliminary analyses of the presence of Bartonella sp. in the deer keds involved 15 L. cervi specimens ( 3 females and 6 males from C. elaphus and 3 females and 3 males from C. capreolus) and 9 L. fortisetosa specimens ( 3 females and 2 males from C. elaphus and 4 females from C. capreolus). In total, Bartonella sp. were detected in $3 / 24(12.5 \%)$ of the studied insects. The presence of the bacteria was shown in only $3 / 9(33.3 \%)$ L. fortisetosa adults $(2 / 7$ of the studied females and $1 / 2$ of studied males). No Bartonella sp. were detected in the L. cervi adults. The derived sequences of Bartonella sp. were submitted to the GenBank database under the accession numbers: MZ061868, MZ061869. The sequences obtained in this study share from 96.6 to $98.3 \%$ similarity with Bartonella sp. Honshu isolated from sika deer blood in Japan (GenBank accession no. AB703145).

The analysis of a $r p o B$ gene fragment yielded two new haplotypes of Bartonella sp.: haplotype H1 (MZ061868) and haplotype H2 (MZ061869), as defined by three polymorphic sites, all being transitions. The maximum-likelihood phylogenetic reconstructions produced a strong topology (Figure 2). The ML tree revealed that our two rpoB haplotypes belong to lineage B described by Sato et al. [51]. The median-joining network based on sequences from this study and haplotypes representing different species of Bartonella obtained from GenBank (Table 1) suggested the presence of a distinct phylogenetic branch created by the discovered haplotypes inside lineage B. It also showed that they are grouped closely with haplotypes H4 (AB703145) and H7 (AB703147) described for new species of Bartonella obtained from Japanese sika deer in Japan (Figure 3).

Table 1. List of species and GenBank accession numbers of their RNA polymerase beta subunit (rpoB) gene sequences used in the network phylogenetic analysis (Figure 3).

\begin{tabular}{|c|c|c|c|}
\hline $\begin{array}{c}\text { Symbol } \\
\text { of Haplotype }\end{array}$ & $\begin{array}{l}\text { Scientific } \\
\text { Name }\end{array}$ & $\begin{array}{c}\text { GenBank } \\
\text { Accession Number }\end{array}$ & $\begin{array}{l}\text { Sequence } \\
\text { Source }\end{array}$ \\
\hline H1 & Bartonella sp. & MZ061868 & This study \\
\hline $\mathrm{H} 2$ & Bartonella sp. & MZ061869 & This study \\
\hline $\mathrm{H} 3$ & Bartonella sp. & AB703144 & Sato et al. [51] \\
\hline $\mathrm{H} 4$ & Bartonella sp. & AB703145 & Sato et al. [51] \\
\hline H5 & Bartonella sp. & AB703146 & Sato et al. [51] \\
\hline H6 & Bartonella sp. & MF580655 & Szewczyk et al. [44] \\
\hline $\mathrm{H7}$ & Bartonella sp. & AB703147 & Sato et al. [51] \\
\hline $\mathrm{H} 8$ & Bartonella sp. & AB703148 & Sato et al. [51] \\
\hline H9 & Bartonella sp. & AB703149 & Sato et al. [51] \\
\hline $\mathrm{H} 10$ & Bartonella capreoli & AB290188 & Inoue et al. [52] \\
\hline H11 & $\begin{array}{c}\text { Bartonella } \\
\text { schoenbuchensis }\end{array}$ & AY167409 & Unpublished \\
\hline H12 & Bartonella bovis & DQ356077 & Unpublished \\
\hline H13 & Bartonella bovis & EF432062 & Maillard et al. [53] \\
\hline H14 & Bartonella bovis & KF218218 & Bai et al. [54] \\
\hline H15 & Bartonella chomelii & JN646664 & Mediannikov et al. [55] \\
\hline $\mathrm{H} 16$ & Bartonella sp. & JQ765388 & Unpublished \\
\hline H17 & Bartonella bovis & KF 218217 & Bai et al. [54] \\
\hline H18 & Bartonella bovis & KF218220 & Bai et al. [54] \\
\hline H19 & Bartonella bovis & KF218224 & Bai et al. [54] \\
\hline $\mathrm{H} 20$ & Bartonella bovis & KJ909808 & Rudoler et al. [56] \\
\hline
\end{tabular}


Table 1. Cont.

\begin{tabular}{cccc}
\hline $\begin{array}{c}\text { Symbol } \\
\text { of Haplotype }\end{array}$ & $\begin{array}{c}\text { Scientific } \\
\text { Name }\end{array}$ & $\begin{array}{c}\text { GenBank } \\
\text { Accession Number }\end{array}$ & $\begin{array}{c}\text { Sequence } \\
\text { Source }\end{array}$ \\
\hline H21 & Bartonella chomelii & KM215709 & Antequera-Gomez et al. [57] \\
H22 & Bartonella chomelii & KM215710 & Antequera-Gomez et al. [57] \\
H23 & Bartonella bovis & KR733194 & Kho et al. [58] \\
H24 & Bartonella bovis & KR733195 & Kho et al. [58] \\
H25 & Bartonella sp. & LC485118 & Sato et al. [51] \\
H26 & Bartonella sp. & MF580656 & Szewczyk et al. [44] \\
H27 & Bartonella sp. & MF580657 & Szewczyk et al. [44] \\
H28 & Bartonella sp. & MF580662 & Szewczyk et al. [44] \\
\hline
\end{tabular}

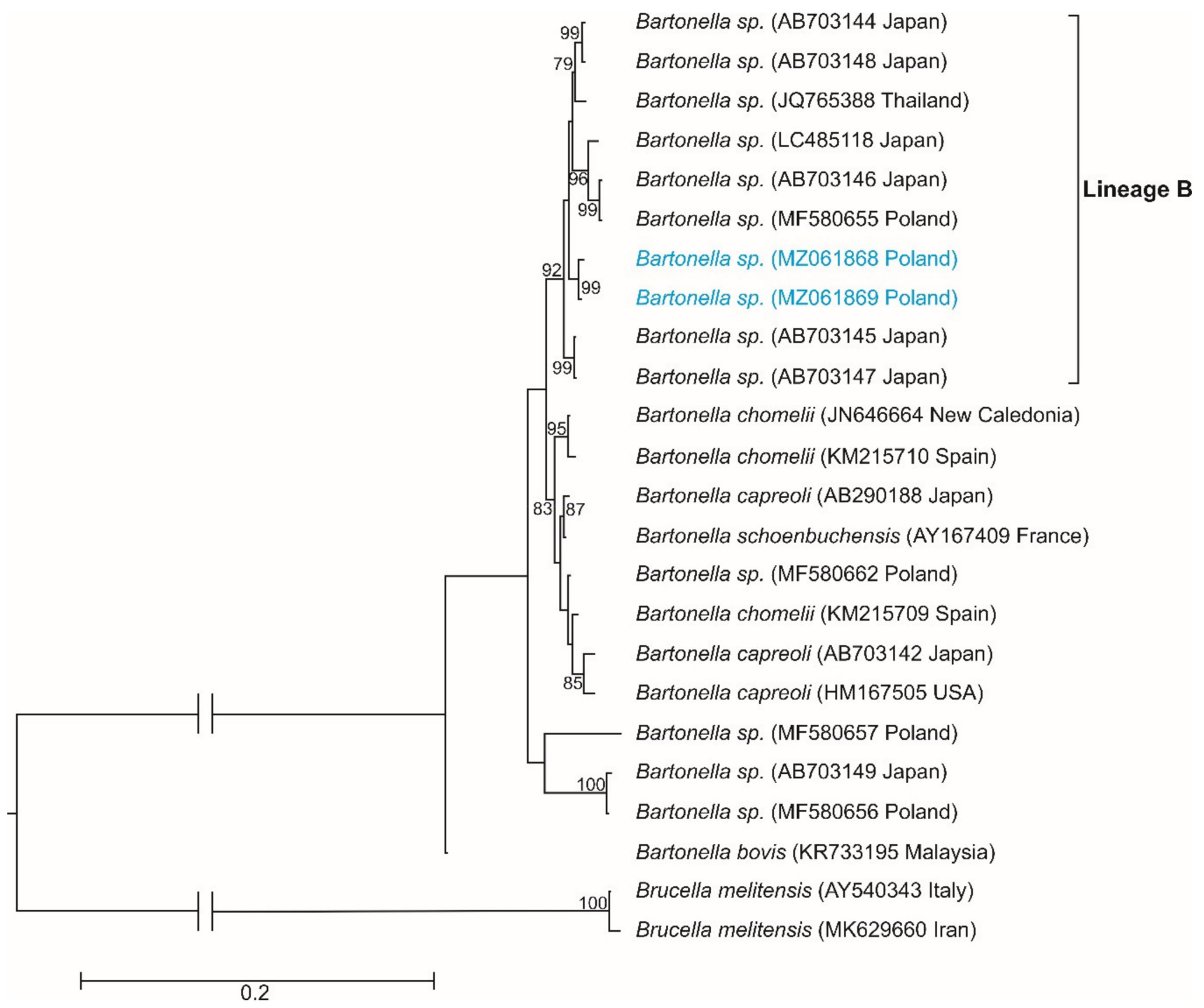

Figure 2. Maximum-likelihood topology computed with the $G T R+I+G$ model of substitution evolution, representing the phylogenetic relationships among the sequences of the rpoB gene for RNA polymerase beta-subunit found in Bartonella sp. Numbers listed at the nodes represent the percent support for the node from 1000 bootstrap replicates. The ML tree has been rooted with sequences of Brucella melitenis, a microorganism closely related with Bartonella sp., as they together belong to the same order, Hyphomicrobiales. The haplotypes of Bartonella sp. found in this study are marked in blue. Lineage B, according to Sato et al. [51]. 


\section{Lineage B}

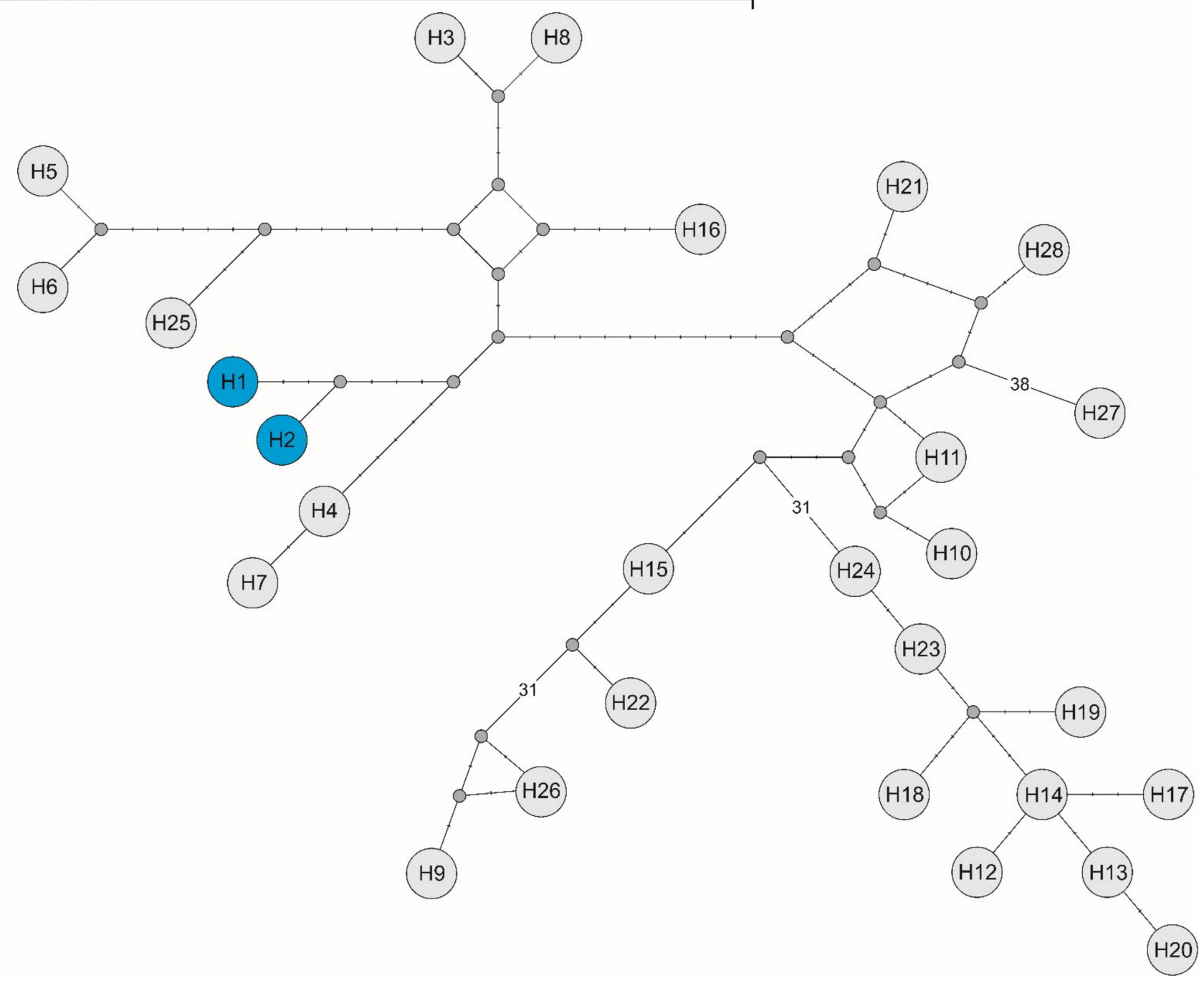

Figure 3. Median-joining network of $r p o \mathrm{~B}$ haplotypes from Poland ( $\mathrm{H} 1$ and $\mathrm{H} 2$, marked with a blue background) and haplotypes of different Bartonella species obtained from GenBank (H3-H28, symbols according to Table 1). Missing haplotypes are indicated by a grey dot.

\section{Discussion}

The zoonotic pathogen Bartonella sp. is a Gram-negative hemotropic bacterium, which is an etiological agent of bartonellosis. The disease usually manifests as an acute or sub-acute febrile illness in humans and animals [59]; however, a long-term symptomless infection with bacteremia in mammalian reservoir hosts (e.g., dogs and cats) was also noted $[55,60,61]$. The role of this bacterium as a causative agent or cofactor in endocarditis has been reported [62,63]. Lipoptena spp. may serve as a potential vector of this bacterium $[34,35,39,40]$.

The prevalence of Bartonella sp. in Lipoptena is high. For instance, Bartonella DNA was detected in $85 \%$ of wingless adults of $L$. cervi collected from free-ranging cervids in Norway [64], and even in $94 \%$ of these deer keds collected from roe deer in France [35]. In Mazury forests (northern part of Poland), Szewczyk et al. showed the prevalence of Bartonella sp. in these insects at the level of $75.12 \%$ [44]. The latest data from northern and western Poland indicate the presence of Bartonella sp. in $49.4 \%$ of L. fortisetosa adults [23]. In turn, the Bartonella sp. infection rate in L. fortisetosa collected in Japan was estimated at $87.9 \%$ by real-time PCR and $51.5 \%$ in culture [ 40$]$. 
In this study, this bacterium was not detected in L. cervi. However, the absence of Bartonella sp. in the studied deer keds may be related to the smaller number of analyzed samples. Five sequences of Bartonella sp. obtained by Szewczyk et al. showed 94.4\% similarity with Bartonella sp. from Japanese sika deer (GenBank accession no. AB703149) [44]. In turn, the two other sequences showed $99.7 \%$ similarity with Bartonella sp. isolated from Japanese sika deer in Wakayama Prefecture, Japan (GenBank accession no. AB703149) and with Bartonella sp. isolated from Japanese sika deer in Nara Prefecture, Japan (GenBank accession no. AB703146). The sequences obtained in this study showed high similarity with Bartonella sp. Honshu isolated from sika deer blood in Japan (GenBank accession no. AB703145) but did not show similarity with the sequences obtained by Szewczyk et al. from L. cervi [44].

In the maximum-likelihood (ML) algorithm based on the rpoB gene sequences, our two haplotypes formed a distinct branch with high bootstrap support within lineage B described by Sato et al. [51]. The ML phylogenetic analyses corroborated the result obtained from the nucleotide network and confirmed that the two haplotypes obtained in this study created a separate branch within the different species of Bartonella. Our newly discovered haplotypes differed by at least nine substitutions from haplotype 4 (GenBank accession no. AB703145, HonshuWD-9.3) and by at least 10 mutations from haplotype 7 (GenBank accession no. AB703147, Bartonella sp. HonshuWD-18.5), both described by Sato et al. [51]. Interestingly, these two GenBank haplotypes of Bartonella were isolated from Japanese sika deer in Japan. As shown by the network analysis, our two haplotypes and haplotypes 4 and 7 created a distinct group together, which additionally supports the view proposed by Sato et al. that lineage B represents a novel Bartonella species [51]. The presence of these two new Bartonella sp. haplotypes in L. fortisetosa and the haplotypes obtained by Szewczyk et al. in L. cervi may suggest that red deer in Poland seem to harbor the novel Bartonella species discovered in Japanese sika deer $[44,51]$. Moreover, it seems to be necessary to obtain and analyze more sequences of Bartonella directly from red deer blood to resolve the relationships of Bartonella species in deer from Japan and Poland. In turn, the role of this deer ked species as a potential vector of this bacterium needs further study.

Author Contributions: Conceptualization, K.B., W.M. and M.Ś.; methodology, K.B., W.M., M.A. and M.Ś.; investigation, K.B., W.M. and E.S.; molecular analysis, M.A., J.W. and M.Ś.; writing-original draft preparation, W.M., E.S., M.A., J.W., P.S.B. and M.Ś.; writing-review and editing, K.B., A.B. and M.Ś.; visualization, K.B., W.M. and M.Ś.; supervision, K.B. All authors have read and agreed to the published version of the manuscript.

Funding: This research received no external funding.

Institutional Review Board Statement: Not applicable.

Data Availability Statement: The original contributions presented in the study are included in the article. Further inquiries can be directed to the corresponding authors.

Acknowledgments: We would like to thank Szymon Kolasa from Polesie National Park, and Ryszard Kiryk for the possibility of an insect collection. We are grateful to Piotr Rode for the help in preparing Figures 2 and 3.

Conflicts of Interest: The authors declare no conflict of interest.

\section{References}

1. Dick, C.W. Checklist of World Hippoboscidae (Diptera: Hippoboscoidea). Available online: https://www.researchgate.net/ publication/322578992_CHECKLIST_OF_WORLD_HIPPOBOSCIDAE_DIPTERA_HIPPOBOSCOIDEA (accessed on 6 July 2019).

2. Petersen, F.T. Fauna Europaea: Hippoboscidae. Fauna Europaea: Diptera, Brachycera. Fauna Europaea. Available online: https:/ / fauna-eu.org (accessed on 10 July 2019).

3. Härkönen, L.; Härkönen, S.; Kaitala, A.; Kaunisto, S.; Kortet, R.; Laaksonen, S.; Ylönen, H. Predicting range expansion of an ectoparasite-The effect of spring and summer temperatures on deer ked Lipoptena cervi (Diptera: Hippoboscidae) performance along a latitudinal gradient. Ecography 2010, 33, 906-912. [CrossRef] 
4. Välimäki, P.; Madslien, K.; Malmsten, J.; Härkönen, L.; Härkönen, S.; Kaitala, A.; Kortet, R.; Laaksonen, S.; Mehl, R.; Redford, L.; et al. Fennoscandian distribution of an important parasite of cervids, the deer ked (Lipoptena cervi), revisited. Parasitol. Res. 2010, 107, 117-125. [CrossRef]

5. Açici, M.; Bölükbas, C.S.; Beyhan, Y.E.; Pekmezci, G.Z.; Gürler, A.T.; Umur, S. Ectoparasites on roe deer (Capreolus capreolus) in Samsun, Turkey. Turk. J. Vet. Anim. Sci. 2012, 36, 456-459.

6. Lazăr, M.; Iacob, O.C.; Solcan, C.; Pașca, S.A.; Lazăr, R.; Boișteanu, P.C. The first report of massive infestation with Lipoptena cervi (Diptera: Hippoboscidae) in Roe Deer (Capreolus capreolus) in Iasi county, N-E of Romania. Arq. Bras. Med. Vet. Zootec. 2014, 69, 293-298. [CrossRef]

7. Jaakola, M.; Ojanen, M.; Hurme, E.; Mutanen, M.; Wahlberg, N.; Välimäki, P.; Kaitala, A. Morphological variation between populations of the expanding ectoparasitic deer ked Lipoptena cervi (Diptera: Hippoboscidae) in Fennoscandia. Biol. J. Linn. Soc. Lond. 2015, 116, 432-448. [CrossRef]

8. Dumčius, O.; Pakalniškis, S. A contribution to the list of Lithuanian Dipteran fauna. New Rare Lith. Insect Spec. 2005, 17, 50-58.

9. Pârvu, C. Diptera from the green corridor of the Danube (Romania). Trav. Mus. Natl. Hist. Nat. Grigore Antipa 2005, 48, 147-176.

10. Ostrovsky, A.M. New findings of Lipoptena fortisetosa Maa, 1965 (Diptera: Hippoboscidae, Lipoptenini) in Belarus. In Proceedings of the Second International Parasitological Symposium: Modern Problems of General and Specific Parasitology, St. Petersburg, Russia, 6-8 November 2017; pp. 208-210. (In Russian).

11. Schedl, W. Lausfliegen an Cervidae und Bovidae in Tirol (Insecta: Diptera, Pupipara, Hippoboscidae). Linz. Biol. Beitr. 2017, 49, 885-894.

12. Andreani, A.; Sacchetti, P.; Belcari, A. Comparative morphology of the deer ked Lipoptena fortisetosa first recorded from Italy. Med. Vet. Entomol. 2019, 33, 140-153. [CrossRef]

13. Kurina, O.; Kirik, H.; Ounap, H.; Õunap, E. The northernmost record of a blood-sucking ectoparasite, Lipoptena fortisetosa Maa (Diptera: Hippoboscidae), in Estonia. Biodivers. Data J. 2019, 13, e47857. [CrossRef]

14. Oboňa, J.; Sychra, O.; Greš, S.; Heřman, P.; Manko, P.; Roháček, J.; Šestáková, A.; Šlapák, J.; Hromada, M. A revised annotated checklist of louse flies (Diptera, Hippoboscidae) from Slovakia. Zookeys 2019, 9, 129-152. [CrossRef]

15. Klepeckienè, K.; Radzijevskaja, J.; Ražanskè, I.; Žukauskienè, J.; Paulauskas, A. The prevalence, abundance, and molecular characterization of Lipoptena deer keds from cervids. J. Vector Ecol. 2020, 45, 211-219. [CrossRef]

16. Kowal, J.; Nosal, P.; Kornaś, S.; Wajdzik, M.; Matusek, M.; Basiaga, M. Biodiversity and importance of hippoboscids infection in cervids. Med. Weter. 2016, 72, 745-749. (In Polish)

17. Mihalca, A.D.; Păstrav, I.R.; Sándor, A.D.; Deak, G.; Gherman, C.M.; Sarmaşi, A.; Votýpka, J. First report of the dog louse fly Hippobosca longipennis in Romania. Med. Vet. Entomol. 2019, 33, 530-535. [CrossRef]

18. Borowiec, L.; Zatwarnicki, T. Lipoptena fortisetosa Maa, 1965 (Diptera, Hippoboscidae), a new species of Polish fauna. Przegl. Zool. 1989, 33, 579-582.

19. Cydzik, K.; Kadulski, S. Parasitic insects of the red deer (Cervus elaphus L.) in the Northern Poland. In Arthropods. Invasions and Their Control; Buczek, A., Błaszak, C., Eds.; Akapit: Lublin, Poland, 2009; pp. 59-66.

20. Jędrysik, D.; Kadulski, S. Parasitic arthropods of roe deer Capreolus capreolus (L.) of the region of the Southern Baltic Lake District. In Arthropods. The Medical and Economic Importance; Buczek, A., Błaszak, C., Eds.; Akapit: Lublin, Poland, 2012; pp. 95-103.

21. Kowal, J.; Nosal, P.; Rościszewska, M.; Matysek, M. New records of Lipoptena fortisetosa Maa, 1965 (Diptera: Hippoboscidae) in Poland. Dipteron 2009, 25, 27-29. (In Polish)

22. Matysek, M.; Kowal, J. Two new species of Diptera. Tatry 2014, 48, 64-65. (In Polish)

23. Gałęcki, R.; Jaroszewski, J.; Bakuła, T.; Galon, E.M.; Xuan, X. Molecular Detection of selected pathogens with zoonotic potential in deer keds (Lipoptena fortisetosa). Pathogens 2021, 10, 324. [CrossRef]

24. Sokół, R.; Gałęcki, R. Prevalence of keds on city dogs in central Poland. Med. Vet. Entomol. 2017, 31, 114-116. [CrossRef]

25. Kadulski, S. The dynamics of infestation of the Cervidae with Lipoptena cervi L. (Diptera, Hippoboscidae) on the territory of Poland. Wiad. Parazytol. 1974, 20, 703-707. (In Polish) [PubMed]

26. Kortet, R.; Härkönen, L.; Hokkanen, P.; Härkönen, S.; Kaitala, A.; Kaunisto, S.; Laaksonen, S.; Kekäläinen, J.; Ylönen, H. Experiments on the ectoparasitic deer ked that often attacks humans; preferences for body parts, colour and temperature. Bull. Entomol. Res. 2010, 100, 279-285. [CrossRef] [PubMed]

27. Laukkanen, A.; Ruoppi, P.; Mäkkinen-Kiljunen, S. Deer ked-induced occupational allergic rhinoconjunctivitis. Ann. Allergy Asthma Immunol. 2005, 94, 604-608. [CrossRef]

28. Buczek, W.; Buczek, A.M.; Bartosik, K.; Buczek, A. Comparison of skin lesions caused by Ixodes ricinus ticks and Lipoptena cervi deer keds infesting humans in the natural environment. Int. J. Environ. Res. Public Health. 2020, 17, 3316. [CrossRef]

29. Maślanko, W.; Bartosik, K.; Raszewska-Famielec, M.; Szwaj, E.; Asman, M. Exposure of humans to attacks by deer keds and consequences of their bites-a case report with environmental background. Insects 2020, 11, 859. [CrossRef]

30. Metelitsa, A.K.; Veselkin, G.A. Parasitism of the louse fly Lipoptena fortisetosa on cattle. Parazitologiia 1989, 23, 276-277. [PubMed]

31. Allan, S.A. Biting flies (class Insecta: Order Diptera). In Parasitic Diseases of Wild Mammals; Samuel, W.M., Pybus, M.J., Kocan, A., Eds.; Iowa State University Press: Iowa City, IA, USA, 2001; pp. 18-45.

32. Hornok, S.; de la Fuente, J.; Biró, N.; Fernández de Mera, I.G.; Meli, M.L.; Elek, V.; Gönczi, E.; Meili, T.; Tánczos, B.; Farkas, R.; et al. First molecular evidence of Anaplasma ovis and Rickettsia spp. in keds (Diptera: Hippoboscidae) of sheep and wild ruminants. Vector Borne Zoonotic Dis. 2011, 11, 1319-1321. [CrossRef] 
33. Buss, M.; Case, L.; Kearney, B.; Coleman, C.; Henning, J.D. Detection of Lyme disease and anaplasmosis pathogens via PCR in Pennsylvania deer ked. J. Vector Ecol. 2016, 41, 292-294. [CrossRef] [PubMed]

34. Dehio, C.; Sauder, U.; Hiestand, R. Isolation of Bartonella schoenbuchensis from Lipoptena cervi, a blood-sucking arthropod causing deer ked dermatitis. J. Clin. Microbiol. 2004, 42, 5320-5323. [CrossRef]

35. Halos, L.; Jamal, T.; Millard, L.; Girard, B.; Guillot, J.; Chomel, B.; Vayssier-Taussat, M.; Boulouis, H.J. Role of Hippoboscidae flies as potential vectors of Bartonella spp. infecting wild and domestic ruminants. Appl. Environ. Microbiol. 2004, 70, 6302-6305. [CrossRef]

36. Duodu, S.; Madslien, K.; Hjelm, E.; Molin, Y.; Paziewska-Harris, A.; Harris, P.D.; Colquhoun, D.J.; Ytrehus, B. Bartonella infections in deer keds (Lipoptena cervi) and moose (Alces alces) in Norway. Appl. Environ. Microbiol. 2013, 79, 322-327. [CrossRef]

37. De Bruin, A.; van Leeuwen, A.D.; Jahfari, S.; Takken, W.; Földvári, M.; Dremmel, L.; Sprong, H.; Földvári, G. Vertical transmission of Bartonella schoenbuchensis in Lipoptena cervi. Parasit. Vectors 2015, 8, 176. [CrossRef] [PubMed]

38. Korhonen, E.M.; Perez Vera, C.; Pulliainen, A.T.; Sironen, T.; Aaltonen, K.; Kortet, R.; Harkonen, L.; Harkonen, S.; Paakkonen, T.; Nieminen, P.; et al. Molecular detection of Bartonella spp. in deer ked pupae, adult keds and moose blood in Finland. Epidemiol. Infect. 2015, 143, 578-585. [CrossRef]

39. Regier, Y.; Komma, K.; Weigel, M.; Pulliainen, A.T.; Göttig, S.; Hain, T.; Kempf, V.A.J. Microbiome analysis reveals the presence of Bartonella spp. and Acinetobacter spp. in deer keds (Lipoptena cervi). Front. Microbiol. 2018, 9, 3100. [CrossRef] [PubMed]

40. Sato, S.; Kabeya, H.; Ishiguro, S.; Shibasaki, Y.; Maruyama, S. Lipoptena fortisetosa as a vector of Bartonella bacteria in Japanese sika deer (Cervus nippon). Parasit Vectors. 2021, 14, 73. [CrossRef]

41. Böse, R.; Petersen, K. Lipoptena cervi (Diptera), a potential vector of Megatrypanum trypanosomes of deer (Cervidae). Parasitol. Res. 1991, 77, 723-725. [CrossRef] [PubMed]

42. Werszko, J.; Steiner-Bogdaszewska, Ż.; Jeżewski, W.; Szewczyk, T.; Kuryło, G.; Wołkowycki, M.; Wróblewski, P.; Karbowiak, G. Molecular detection of Trypanosoma spp. in Lipoptena cervi and Lipoptena fortisetosa (Diptera: Hippoboscidae) and their potential role in the transmission of pathogens. Parasitology 2020, 147, 1629-1635. [CrossRef]

43. Lee, S.H.; Kim, K.T.; Kwon, O.D.; Ock, Y.; Kim, T.; Choi., D.; Kwak, D. Novel detection of Coxiella spp., Theileria luwenshuni, and T. ovis endosymbionts in deer keds (Lipoptena fortisetosa). PLoS ONE 2016, 11, e0156727. [CrossRef]

44. Szewczyk, T.; Werszko, J.; Steiner-Bogdaszewska, Ż.; Jeżewski, W.; Laskowski, Z.; Karbowiak, G. Molecular detection of Bartonella spp. in deer ked (Lipoptena cervi) in Poland. Parasit. Vectors 2017, 10, 487. [CrossRef]

45. Borowiec, L. Keys for Identification of Polish Insects; Polish Entomological Society PWN: Warszawa, Poland, 1984; pp. 1-40. (In Polish)

46. Guy, E.; Stanek, G. Detection of Borrelia burgdorferi in patients with Lyme disease by the polymerase chain reaction. J. Clin. Pathol. 1991, 29, 610-611. [CrossRef] [PubMed]

47. Renesto, P.; Gouvernet, J.; Drancourt, M.; Roux, V.; Raoult, D. Use of rpoB analysis for detection and identification of Bartonella species. J. Clin. Microbiol. 2001, 3, 430-437. [CrossRef]

48. Hall, T.A. BioEdit: A user-friendly biological sequence alignment editor and analysis program for Windows 95/98/NT. Nucleic Acids Symp. Ser. 1999, 41, 95-98.

49. Tamura, K.; Peterson, D.; Peterson, N.; Stecher, G.; Nei, M.; Kumar, S. MEGA5: Molecular evolutionary genetics analysis using maximum likelihood, evolutionary distance, and maximum parsimony methods. Mol. Biol. Evol. 2011, 28, 2731-2739. [CrossRef] [PubMed]

50. Posada, D. jModelTest: Phylogenetic model averaging. Mol. Biol. Evol. 2008, 25, 1253-1256. [CrossRef] [PubMed]

51. Sato, S.; Kabeya, H.; Yamazaki, M.; Takeno, S.; Suzuki, K.; Kobayashi, S.; Souma, K.; Masuko, T.; Chomel, B.B.; Maruyama, S. Prevalence and genetic diversity of Bartonella species in sika deer (Cervus nippon) in Japan. Comp. Immunol. Microbiol. Infect. Dis. 2012, 35, 575-581. [CrossRef]

52. Inoue, K.; Maruyama, S.; Kabeya, H.; Yamada, N.; Ohashi, N.; Sato, Y.; Yukawa, M.; Masuzawa, T.; Kawamori, F.; Kadosaka, T.; et al. Prevalence and genetic diversity of Bartonella species isolated from wild rodents in Japan. Appl. Environ. Microbiol. 2008, 74, 5086-5092. [CrossRef]

53. Maillard, R.; Petit, E.; Chomel, B.; Lacroux, C.; Schelcher, F.; Vayssier-Taussat, M.; Haddad, N.; Boulouis, H.J. Endocarditis in cattle caused by Bartonella bovis. Emerging Infect. Dis. 2007, 13, 1383-1385. [CrossRef]

54. Bai, Y.; Malania, L.; Alvarez Castillo, D.; Moran, D.; Boonmar, S.; Chanlun, A.; Suksawat, F.; Maruyama, S.; Knobel, D.; Kosoy, M. Global distribution of Bartonella infections in domestic bovine and characterization of Bartonella bovis strains using multi-locus sequence typing. PLOS ONE 2013, 8, E80894. [CrossRef]

55. Mediannikov, O.; Davoust, B.; Cabre, O.; Rolain, J.M.; Raoult, D. Bartonellae in animals and vectors in New Caledonia. Comp. Immunol. Microbiol. Infect. Dis. 2011, 34, 497-501. [CrossRef]

56. Rudoler, N.; Rasis, M.; Sharir, B.; Novikov, A.; Shapira, G.; Giladi, M. First description of Bartonella bovis in cattle herds in Israel. Vet. Microbiol. 2014, 173, 110-117. [CrossRef]

57. Antequera-Gomez, M.L.; Lozano-Almendral, L.; Barandika, J.F.; Gonzalez-Martin-Nino, R.M.; Rodriguez-Moreno, I.; GarciaPerez, A.L.; Gil, H. Bartonella chomelii is the most frequent species infecting cattle grazing in communal mountain pastures in Spain. Appl. Environ. Microbiol. 2015, 81, 623-629. [CrossRef]

58. Kho, K.L.; Koh, F.X.; Jaafar, T.; Hassan Nizam, Q.N.; Tay, S.T. Prevalence and molecular heterogeneity of Bartonella bovis in cattle and Haemaphysalis bispinosa ticks in Peninsular Malaysia. BMC Vet. Res. 2015, 11, 153. [CrossRef] [PubMed] 
59. Breitschwerdt, E.B.; Maggi, R.G.; Chomel, B.B.; Lappin, M.R. Bartonellosis: An emerging infectious disease of zoonotic importance to animals and human beings. J. Vet. Emerg. Crit. Care 2010, 20, 8-30. [CrossRef]

60. Jacomo, V.; Kelly, P.J.; Raoult, D. Natural history of Bartonella infections (an exception to Koch's postulate). Clin. Diagn. Lab. Immunol. 2002, 9, 8-18. [CrossRef]

61. Chomel, B.B.; Kasten, R.W.; Sykes, J.E.; Boulouis, H.J.; Breitschwerdt, E.B. Clinical impact of persistent Bartonella bacteremia in humans and animals. Ann. N. Y. Acad. Sci. 2003, 990, 267-278. [CrossRef]

62. Brouqui, P.; Raoult, D. Endocarditis due to rare and fastidious bacteria. Clin. Microbiol. Rev. 2001, 14, 177-207. [CrossRef]

63. Donovan, T.A.; Balakrishnan, N.; Carvalho Barbosa, I.; McCoy, T.; Breitschwerdt, E.B.; Fox, P.R. Bartonella spp. as a possible cause or cofactor of feline endomyocarditis-left ventricular endocardial fibrosis complex. J. Comp. Pathol. 2018, 162, 29-42. [CrossRef] [PubMed]

64. Razanske, I.; Rosef, O.; Radzijevskaja, J.; Klepeckiene, K.; Lipatova, I.; Paulauskas, A. Infections with Bartonella spp. in freeranging cervids and deer keds (Lipoptena cervi) in Norway. Comp. Immunol. Microbiol. Infect. Dis. 2018, 58, 26-30. [CrossRef] [PubMed] 